Opinion and View

\title{
Corn and Cellulosic Ethanol Cause Major Problems
}

\author{
David Pimentel ${ }^{1, *}$ and Marcia Pimentel ${ }^{2}$ \\ ${ }^{1}$ Professor Emeritus of Ecology and Agricultural Sciences, Department of Entomology, College of \\ Agriculture and Life Sciences, Cornell University, Ithaca, NY 14853, USA \\ ${ }^{2}$ Senior Lecturer, Division of Nutritional Sciences, College of Human Ecology, Cornell University, \\ Ithaca, NY 14853, USA
}

* Author to whom correspondence should be addressed; E-mail: dp18@cornell.edu

Received: 6 June 2008 / Accepted: 16 June 2008 / Published: 17 June 2008

Abstract: Crops for biofuels squanders cropland, water, and energy resources vital for food production needed for people.

Keywords: Biofuels, bioethanol, biomass

The diminishing supply of oil and high prices is encouraging the conversion of grain or other biomass into ethanol fuel. Using corn and cellulosic biomass for ethanol requires large cropland areas, large quantities of water, and sunlight for green plant production.

All green plants in the U.S., including all crops, forest, and grasses, combined collect only about 70 quads (32 x $10^{15} \mathrm{BTU}$ ) of sunlight energy per year. Meanwhile, Americans use slightly more than 3 times that amount as fossil fuels [1]!

Enthusiasts suggest ethanol produced from corn grain and cellulosic biomass, like grasses, could replace much of the oil used in U.S. In 2007, when 20\% of the U.S. corn crop was converted into 6 billion gal of ethanol, it replaced only $1 \%$ of U.S. oil consumption [2]. If the entire corn crop were converted, it would replace a mere $7 \%$ of oil consumption - and certainly not make the U.S. independent of foreign oil!

Several scientific analyses confirmed that 14 energy inputs go into corn production, plus an additional 9 energy inputs are invested in fermentation and distillation operations. This confirms that more than $140 \%$ more energy (mostly high value oil and natural gas) is expended to produce a gallon of corn ethanol than is in the ethanol itself. Some investigators omit several of the energy inputs 
required in corn production and processing, such as energy for farm labor, farm machinery, energy production of hybrid corn-seed, irrigation, and processing equipment [3].

Cellulosic ethanol is being touted as the replacement for corn ethanol. Unfortunately, cellulose biomass contains only minimal amounts of starches and sugars and therefore requires major fossil energy inputs to release these tightly bound starches and sugars. With existing technology, about $170 \%$ more energy (oil and gas) is required to produce ethanol from cellulosic biomass than is in the ethanol produced [4].

The production of corn ethanol is highly subsidized by U.S. government by more than $\$ 6$ billion per year according to a 2006 report, "Biofuels - at What Cost? Government Support for Ethanol and Biodiesel in the United States," released by the International Institute for Sustainable Development in Geneva. These subsidies for a gallon of ethanol are more than 60 times greater those for a gallon of gasoline.

The environmental impacts of corn ethanol are serious and diverse. These include severe soil erosion of our valuable cropland, plus the heavy use of nitrogen fertilizer and pesticides that pollute rivers. During the fermentation process, about $25 \%$ of the carbon from the sugars and starches is released as carbon dioxide into the atmosphere. These major releases of carbon dioxide significantly contribute to global warming. Also, each gallon of ethanol requires 1700 gallons of water (mostly to grow the corn) and releases 12 gallons of noxious sewage effluent from the fermentation process into the environment [5].

Using food crops, such as corn grain, to produce ethanol raises major nutritional and ethical concerns. With nearly $60 \%$ of humans in the world now currently malnourished, the need for grains and other basic food crops continues to be critical [6]. Associated with the use of corn for ethanol are increases in the price of U.S. beef, chicken, pork, eggs, breads, cereals, and milk of $10 \%$ to $100 \%$. Jacques Diouf, Director General of the U.N. Food \& Agriculture Organization, warns that using corn for ethanol is causing food shortages for the poor worldwide [7].

Basically growing crops for biofuels squanders cropland, water, and energy resources vital for food production needed for people.

\section{References and Notes}

1. Pimentel, D. Celluosic ethanol problems and soil erosion. 2008, draft manuscript.

2. Pimentel, D.; Patzek, T.; Cecil, G. Ethanol production: energy, economic, and environmental losses. Rev. Environ. Contam. Toxicol. 2007, 189, 25-41.

3. Shapouri, H.; Duffield, J.A.; Wang, M. The Energy Balance of Corn Ethanol: An Update. USDA, Office of Energy Policy and New Uses, Agricultural Economics. 2002, Report No. 813. 14 p.

4. Pimentel, D.; Marklein, A.; Toth, M.; Karpoff, M.; Gillian, G.; McCormack, R.; Kyriazis, J.; Krueger, T. Food versus biofuels: environmental and economic costs. Energy and Environment 2008, in press.

5. Pimentel, D.; Marklein, A.; Toth, M.; Karpoff, M.; Gillian, G.; McCormack, R.; Kyriazis, J.; Krueger, T. Food versus biofuels. 2008, draft manuscript.

6. Pimentel, D.; Pimentel, M. eds. Food, Energy and Society. 3rd Edition. CRC Press (Taylor and Francis Group): Boca Raton, FL. 380 pp. 2007. 
7. United Nations Radio, Climate Change and Bio-Fuel Threaten Food Security, FAO Chief, November 26, 2007, www.un.org/radio/news/html/16436.html (1/22/2008)

(C) 2008 by the authors; licensee Molecular Diversity Preservation International, Basel, Switzerland. This article is an open-access article distributed under the terms and conditions of the Creative Commons Attribution license (http://creativecommons.org/licenses/by/3.0/). 